THE NATION IN THE HISTORY OF MARXIAN THOUGHT 


\section{THE NATION IN THE HISTORY OF MARXIAN THOUGHT}

THE CONCEPT OF NATIONS WITH HISTORY AND NATIONS WITHOUT HISTORY

$$
\text { by }
$$

CHARLES C. HEROD

State University of New York at Plattsburgh

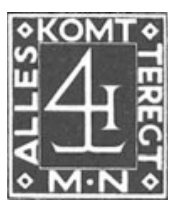

SPRINGER-SCIENCE+BUSINESS MEDIA, B.V. 1976 
To

Robert A. Kann

Teacher and Friend

(c) Springer Science+Business Media Dordrecht 1976

Originally published by Martinus Nijhoff, The Hague, Netherlands in 1976

All rights reserved, including the right to translate or to

reproduce this book or parts thereof in any form

ISBN 978-94-017-4575-8

DOI 10.1007/978-94-017-4754-7

ISBN 978-94-017-4754-7 (eBook) 


\section{TABLE OF CONTENTS}

Chapter I: Origin of the Theory of Nations with History AND NATIONS Without HistoRy

A. Karl Marx and Friedrich Engels as editors of the Neue Rheinische Zeitung

B. Discussion of the concept of nations with history and nations without history in the Neue Rheinische Zeitung

C. Marx and Engels attitude towards small Slavic national groups after the demise of the Neue Rheinische Zeitung

Chapter II: Marxist Theorists on the Evolution of the Concept of Nations with History aNd Nations without HISTORY

A. The reappearance in socialist literature of the concept of nations with history and nations without history at the end of the Igth century

B. Karl Kautsky, Otto Bauer and their exchange of views

C. Conflict within German social democratic party that brought the discussion of the concept of nations with history and nations without history to the fore in I9I5

D. Discussion of Rosa Luxemburg's theories for the renascence of the Polish nation

E. Comparative comments on the views of Otto Bauer and Rosa Luxemburg in their historical setting 
Chapter III: Attitude of 20th Century Marxists towards Question of the Right of National Self-Determination FOR SMALl National Groups

A. The right of national self-determination championed by international social democracy IOO

CHAPTER IV: CONCLUSION I20

Bibliography I30

Index 